\title{
Mész- és cementgyári porok növényfiziológiai hatásának vizsgálata
}

\author{
TÓTH BRIGITTA-VERES SZILVIA-BÁKONYI NÓRA-GAJDOS ÉVA- \\ MAROZSÁN MARIANNA-LÉVAI LÁSZLÓ \\ Debreceni Egyetem Agrár- és Gazdálkodástudományok Centruma \\ Növénytudományi Intézet, \\ Mezőgazdasági Növénytani és Növényélettani Tanszékcsoport, Debrecen
}

\section{Összefoglalás}

Környezetünk védelme közös feladat. Minden szennyezés, ami földjeinket, növényeinket, a szúkebb, vagy a tágabb értelemben vett környezetünket éri, előbb-utóbb megjelenik az élelmiszerlánc valamelyik tagjában, végül a piramis csúcsán álló emberben.

Munkánk célja egy átlátható képet adni néhány ipari hulladék - cementpor, mészpor, mészhidrátpor - növényekre gyakorolt fiziológiai hatásáról. A vizsgált anyagok a növények számára sok létfontosságú elemet tartalmaznak (pl.: vas, kálium, magnézium, foszfor, cink), de mindezek mellett alumínium, ólom, króm és kobalt is megtalálható bennük. Ezek figyelembevételével vizsgáltuk a csírázásra gyakorolt hatást, a növények elemfelvételét, a száraz anyag felhalmozást és a relatív klorofill tartalmat. A laboratóriumi kísérletek során bizonyítottá vált a cementpor, a mészpor és a mészhidrátpor kedvezô és kedvezőtlen fiziológiai hatása. Kétségtelen, hogy a laboratóriumban a környezet kompenzáló hatása kizárt, azonban a környezeti terhelések semlegesítése természetes körülmények között sem végtelen.

Kulcsszavak: ipari szennyezés, cementpor, elemtartalom, relatív klorofill tartalom 


\title{
Effect of quick-lime and cement factory powder on some plant physiology parameters
}

\author{
B. TÓTH-SZ. VERES-N. BÁKONYI-É. GAJDOS-M. MAROZSÁN-L. LÉVAI \\ University of Debrecen, Centre for Agricultural and Applied Economic Sciences, \\ Institute of Plant Science, Division of Agricultural Botany and Crop Physiology, \\ Debrecen
}

\begin{abstract}
Summary
The protection of our environment is a common task. All pollution that exposes our soils, plants or environment in the narrower and wider sense will appear sooner or later in the food chain and in human beings who are at the peak of the food-chain pyramid.

The aim of our work is to give a brief overview of the effects of some industrial wastes - cement dust, lime powder and lime hydrate powder - on the physiological parameters of plants. These materials contain lots of useful elements for plants (e.g. iron, potassium, magnesium, phosphorus, zinc). But, their aluminium, lead, chrome and cobalt contents are also considerable. The germination rate of experimental plants was examined, and. the uptake of elements, the dry matter accumulation and relative chlorophyll contents were also measured. Disadvantageous and advantageous physiological effects of cement dust, lime powder and lime hydrate powder were shown. The compensation effect of environment is excluded, however, the neutralisation of environment loads are not infinite in natural circumstances.
\end{abstract}

Key words: industrial pollution, cement powder, contents of elements, relative chlorophyll content

\section{Bevezetés és irodalmi áttekintés}

Napjaink kutatásának egyik központi témája az éghajlatváltozás hatásainak vizsgálata. Az egymást követô években az eltérô hômérséklet és csapadékmennyiség, valamint annak eloszlása közel azonos termesztési feltételek esetén is jelentôsen befolyásolhatja a termés mennyiségét (Nagy 2006). A globális klímaváltozás okán a talajok állapota és nedvességtartalma az eddigieknél is több, és alaposabb figyelmet kíván (Birkás 2009). 
A klíma folyamatos melegedésén túl a savas esók a növényzet pusztulását eredményezhetik. Talajaink elsavanyodása nem csupán a savas esôk következménye, hanem közvetlenül mezôgazdasági, ipari szennyezés is okozhatja. Számottevő́en csökkenhet a talajok puffer kapacitása, és a pH is, aminek eredményeként fokozódik a nehézfémek felvétele. Amellett, hogy ezek a hulladékok befolyásolják a talaj pH-ját, számos hasznos és káros elemet is tartalmaznak. Nincs meggyőzó bizonyíték arra, hogy az alumínium, akár az akkumulátor fajoknál, esszenciális elem lenne. Ugyanakkor többen kimutatták a talaj, vagy a tápoldat alacsony alumínium koncentrációjának kedvezô hatását a növények növekedésére (Bollard 1983, Foy 1983). A kukorica, a cukorrépa növekedésére kedvezô hatású alumínium koncentráció 71,4-185 $\mu \mathrm{M}$ volt. Az egyik leginkább alumínium toleráns növénynél, a teanál $1.000 \mu \mathrm{M}$ nél határozott növekedésserkentést figyeltek meg (Matsumoto et al. 1976), sôt még $6.400 \mu \mathrm{M}$ alumínium koncentrációnál is hasonló hatást tapasztaltak (Konishi et al. 1985).

Növekszik más nehézfémek felvétele is a pH csökkenésével. A kadmium fokozott felvétele, ha közvetetten is, de egészséget veszélyeztető folyamat. A kadmium a talajban erôsen kötődik, a kadmium általában addig a mélységig jut le a talajprofilba, ameddig a talajmúveléssel bedolgozták. Ezért veszélyes mértékben is felhalmozódhat a talaj felsô rétegében (Filep et al. 1998). A talajok átlagos kadmium tartalma néhány tized $\mathrm{mg} / \mathrm{kg}$, azonban ettől magasabb (1 $\mathrm{mg} / \mathrm{kg}$ ) értékek is előfordulhatnak (Kádár 1991). A kadmium gátolja a nem toleráns növények növekedését és fejlődését (Pinto et al. 2004). A fitotoxicitásán túl közvetve is hat, azáltal, hogy a talaj mikroorganizmusaira is potenciális veszélyt jelent (Duxbury 1985). A kadmium okozta veszélyforrás felfedezését a gyakorlati növénytermesztésben nehezíti, hogy gazdasági növényeink gyakran látható tünetek nélkül, nagy mennyiségben halmozhatják fel. Fôleg levélzöldségekre jellemző, hogy sok kadmiumot akkumulálnak, de például napraforgóban is megfigyeltek kadmium dúsulást a talaj kadmium tartalmának növelésével (Kádár et al. 1998, Simon et al. 1999, Vér 2006).

Ugyanakkor a magas pH-jú talajokon, amelyek gyakoriak a száraz és a félszáraz klimatikus viszonyok között, a vas növények általi felvehetôsége erósen gátolt lehet. Vashiányos körülmények között a növények fiatal levelei megsárgulnak (klorózis), és a növekedés mérséklődik, a termés csökken. A vashiányos körülmények között élő növények gyökereinek válaszreakciói segítik a vas felvételét. A növények vastartalmának szinte túlnyomó része a kloroplasztiszok- 
ban van. A vas maradék része megoszlik a citoplazma és más sejtorganellumok között, amelyek egyéb hem-, illetve vas-kén proteineket tartalmaznak (Miller et al. 1995).

\section{Anyag és módszer}

A mészporok egy mészüzem (Kalcinátor Kft.), a cementpor egy cementgyár (Holcim Zrt.) különbözô szúroóibôl származnak. A cementgyárban egylépcsôs szúróberendezés üzemel, az onnan gyújtött por jelölése a továbbiakban: „C”. A mészüzemben kétlépcsôs szúrôberendezés üzemel. Az elsố a nagyobb szemcseméretű, gyorsan ülepedô port választja le, ennek a jelölése $\mathrm{P}_{1}$; a második lépcső a kis szemcseméretú, finomabb, lebegố port, ezt $\mathrm{P}_{2}$-vel jelöljük. A mészhidrát üzem szúrőberendezéséből származó por jelölése: „H”.

A gyárakból kijutott por természetének pontosabb vizsgálatához további lerakódott pormintákat gyújtöttünk a kijelölt zónába eső házak tetejérôl is (a házak tetejérôl gyújtött pormintát „T”-vel jelölöm) úgy, hogy a finom ecsettel sepertük össze a tetőre rakódott port.

A mintavételi terület kijelölésekor az uralkodó szélirányba (ÉK) esó területet vettük figyelembe. Ez a terület Miskolc kertvárosa. A gyár területét középpontnak tekintve 200-400-600-800 méteres izovonalakhoz köthetó ingatlanok tulajdonosainak engedélyével levélmintákat gyújtöttünk a kertjeikben lévô gyümölcsfák (alma - Malus sieboldii, körte - Pyrus elaeagrifolia) leveleiból a további vizsgálatokhoz. Az említett izovonalak mentén 3 helyrôl történt a mintavétel, a fák lombkoronájának alsó részének észak-keleti tájolásából 5-7 éves fákról 5-5 levelet gyújtöttünk.

A laboratóriumi vizsgálatokban kísérleti növényként kukoricát (Zea mays L. cv. Norma sc), illetve napraforgót (Helianthus annus L.) használtunk. A magvak felületének fertôtlenítését 5-szörös hígítású $\mathrm{H}_{2} \mathrm{O}_{2}$-vel végeztük el. A fertőtlenített magvakat desztillált vízzel többször öblítettük, majd $10 \mathrm{mM}$ $\mathrm{CaSO}_{4}$ oldatban 4 óráig áztattuk a jobb csírázás érdekében. A magvakat nedves szúrôpapír között termosztátban csíráztattuk, úgy, hogy a csíranövények polaritása természetes legyen. A termosztát hőmérséklete $22{ }^{\circ} \mathrm{C}$ volt. A 4 cm-es hipokotilú napraforgó, és az ugyanekkora koleoptillel bíró kukorica csíranövényeket tápoldatra helyeztük. A növények neveléséhez az alábbi összetételú tápoldatot használtuk: 2,0 mM Ca(NO 3$) 2,0,7 \mathrm{mM} \mathrm{K}_{2} \mathrm{SO}_{4}, 0,5 \mathrm{mM} \mathrm{MgSO} 4,0,1 \mathrm{mM}$ $\mathrm{KH}_{2} \mathrm{PO}_{4}, 0,1 \mathrm{mM} \mathrm{KCl}, 10 \mu \mathrm{M} \mathrm{H}_{3} \mathrm{BO}_{3}, 1 \mu \mathrm{M} \mathrm{MnSO}_{4}, 1 \mu \mathrm{M} \mathrm{ZnSO}_{4}, 0,2 \mu \mathrm{M} \mathrm{CuSO}_{4}$, 
$0,01 \mu \mathrm{M}\left(\mathrm{NH}_{4}\right)_{6} \mathrm{Mo}_{7} \mathrm{O}_{24}$. A növények a vasat $10^{-4} \mathrm{M}$ FeEDTA formában kapták. A tápoldat pH-ja 4,40 volt. A környezeti feltételek szabályozottak voltak: a fényintenzitás $300 \mu \mathrm{mol} \mathrm{m} \mathrm{m}^{-2}$, a hômérséklet periodicitása $25 / 20^{\circ} \mathrm{C}$ (nappal/éjjel), a relatív páratartalom ( $\mathrm{RH}$ ) 65-75\%, a megvilágítás/sötét periódus 16 óra/8 óra volt. A gyári szúrôkbôl vett port 1,25 $\mathrm{g} \mathrm{dm}^{3}$, illetve $12,5 \mathrm{~g} \mathrm{dm}^{-3}$ koncentrációban adtuk a tápoldathoz. A vizsgálatokat 3 ismétlésben végeztük. A kukorica esetében 10, a napraforgónál 12 nap után számoltuk fel a kísérletet. A kísérlet felszámolásakor a gyökereket és hajtásokat külön-külön gyújtöttük, a gyökereket 0,1 n HCL oldattal, majd ioncserélt vízzel öblítettük le. A begyújtött porok és a növényi minták elemtartalmának meghatározásához egy OPTIMA 3300 DV típusú induktív csatolású plazma optikai emissziós spektrométert (ICP-OES) alkalmaztunk. A vizsgálatainkban a háttérmérés helyéül általában 2-pontos háttérkorrekciót alkalmaztunk. Az elemtartalom mérését a minták előkészítése előzte meg, amely magába foglalja a mintákból 1 g kimérését, a növényi minták porítását. Ezt követte az előroncsolás, mely során $10 \mathrm{~cm}^{3}$ desztillált cc. $\mathrm{HNO}_{3}$-at alkalmaztunk $60^{\circ} \mathrm{C}$-on 30 percig. A fôroncsolás elôtt 3 $\mathrm{cm}^{3} 30 \%$-os $\mathrm{H}_{2} \mathrm{O}_{2}$-ot adagoltunk a mintákhoz, a fơroncsolás 90 percig és 120 ${ }^{\circ} \mathrm{C}$-on történt. A roncsolmány lehúlése után $50 \mathrm{~cm}^{3}$-re töltöttük ioncserélt vízzel, majd Filtrak 388 szúrốpapírral szúrtük. Az analitikai vizsgálathoz a mintákat egyesítettük.

A relatív klorofill tartalmat SPAD 502 (MINOLTA, Japán) klorofill mérôvel mértük. A száraz tömeg meghatározásához a mintákat $85^{\circ} \mathrm{C}$-on tömegállandóságig szárítottuk, majd szobahômérsékletre történő visszahútés után analitikai mérlegen (OHAUS) mértük.

A toxicitási teszthez mustármagokat használtunk. A porokat a Petri-csésze aljára helyezett szúroópapírra terítettük, majd nedvesítettük és nedves szúrôpapírral fedtük. A mustár magvakból minden Petri-csészébe 100 szemet raktunk. Négy kezelést (cementpor, mészhidrátpor, 2 mintavételi helyrôl származó mészpor) és egy kontrollt állítottunk be, két ismétlésben. Egy hétig figyeltük a csírázási képességet.

A kapott adatok, eredmények kiértékelése Microsoft Sigma Plot 2.7 és SPSS 13.0 programokkal történt. 


\section{Eredmények és következtetések}

A vizsgálatok elvégzéséhez szükség volt a porok elemtartalmának elôzzetes meghatározására. A vizsgálatok eredményeit az 1. táblázat mutatja be, mely szerint a különbözó helyekrốl származó porok számos elemet tartalmaznak. A gyártási folyamatokban alapvetóen mészkövet használnak fel, ezért a por elem összetétele tükrözi az alapanyag összetételét, amit a magas kalcium tartalom igazol.

Az alumínium koncentrációja a tetôrốl származó mintában (T) kb. 90-szer nagyobb volt, mint a hidrát porban $(\mathrm{H})$. A mészüzemból származó két minta között is különbség figyelhetố meg, az elemek koncentrációja a Mg-ot kivéve magasabb a második mintavételi helyrốl származó mintában. A kalcium - az elemek többségétôl eltérôen - a tetőkről származó mintában kb. csak fele koncentrációban volt kimutatható, mint a mész- és a mészhidrát üzemekbool származó porokban. A króm a mészhidrát-porhoz képest mintegy 20-szor, a cementporhoz képest 4,5-szer nagyobb mennyiségben volt jelen a tetôkről származó mintában; a réznél ez a mennyiség 36-szor a mészhidrát-porhoz és a cementporhoz képest 5,6-szor nagyobb. A vas a tetôkrốl származó mintában kb. 160-szor nagyobb koncentrációban volt kimutatható, mint a mészhidrátüzemi porban. Míg az ólom és a kén, a mész-és a mészhidrát-üzemi mintákban a kimutatási határérték alatt maradt, addig a cementporban és a tetôkrôl származó mintákban magas koncentrációban mutatható ki.

A mérések kimutatták, hogy a tetôn néhány elem rendkívüli koncentrációban halmozódott fel. Ennek oka az elemek alacsony oldhatósága, amely miatt a tetốról a csapadék nem tudta lemosni, hanem folyamatosan felhalmozódtak. Okunk van feltételezni, hogy a por kiülepedése egyenletesen történt, ezért a házakhoz tartozó kertek talajában is hasonló vagy nagyobb felhalmozódás lehet.

Az uralkodó szélirányba esố területekrôl vett növények vizsgálatát az indokolta, hogy a házak tetejérôl vett mintákban nagy mennyiségben tapasztaltuk a különbözó fémionok felhalmozódását. A vizsgálatunk meglepő eredményt hozott (2. táblázat). A levelek elemtartalmának meghatározásakor azt tapasztaltuk, hogy a kontrollként választott, Bükki Nemzeti Park területéról vett mintában (vadkörte, Pyrus pyraster) a vizsgált elemek nagyobb mennyiségben voltak jelen, mint az általunk szennyezettnek ítélt területen. 
1. táblázat. Az elemek összes koncentrációja a különbözố szürôkból vett mintában és tetóról vett pormintában $(\mathrm{mg} / \mathrm{kg})$

\begin{tabular}{|c|c|c|c|c|c|}
\hline \multirow{2}{*}{$\begin{array}{c}\text { Elemek } \\
(\mathrm{mg} / \mathrm{kg}) \\
(2)\end{array}$} & \multicolumn{5}{|c|}{$\begin{array}{l}\text { A porok származási helyei } \\
\text { (1) }\end{array}$} \\
\hline & P1 & P2 & $\mathrm{C}$ & $\mathrm{H}$ & $\mathrm{T}$ \\
\hline $\mathrm{Al}$ & 1491,00 & 6939,00 & 6426,00 & 229,00 & 20143,00 \\
\hline B & 3,94 & 6,69 & 10,20 & 3,02 & 49,20 \\
\hline $\mathrm{Ba}$ & 2,63 & 8,20 & 19,80 & 1,17 & 123,00 \\
\hline $\mathrm{Ca}$ & 544031,00 & 668500,00 & 153851,00 & 596301,00 & 301226,00 \\
\hline $\mathrm{Cd}$ & 0,80 & 2,05 & 3,90 & 0,31 & 3,54 \\
\hline Co & 0,54 & 1,28 & 2,41 & $<\mathrm{KH}$ & 5,94 \\
\hline $\mathrm{Cr}$ & 3,92 & 6,26 & 11,80 & 2,60 & 53,90 \\
\hline $\mathrm{Cu}$ & 2,64 & 3,45 & 10,70 & 1,66 & 60,20 \\
\hline $\mathrm{Fe}$ & 1067,00 & 1980,00 & 12941,00 & 160,00 & 25648,00 \\
\hline $\mathrm{K}$ & 742,00 & 2101,00 & 4185,00 & 162,00 & 2727,00 \\
\hline $\mathrm{La}$ & 5,32 & 13,60 & 7,77 & 5,13 & 21,00 \\
\hline $\mathrm{Li}$ & 1,41 & 3,84 & 9,88 & 0,18 & 11,50 \\
\hline $\mathrm{Mg}$ & 4084,00 & 3688,00 & 3802,00 & 2882,00 & 6214,00 \\
\hline Mn & 65,80 & 134,00 & 274,00 & 50,50 & 652,00 \\
\hline $\mathrm{Na}$ & 278,00 & 398,00 & 1333,00 & 279,00 & 2854,00 \\
\hline $\mathrm{Ni}$ & 6,71 & 8,40 & 9,24 & 2,10 & 56,90 \\
\hline$P$ & 115,00 & 181,00 & 220,00 & 101,00 & 1661,00 \\
\hline $\mathrm{Pb}$ & $<\mathrm{KH}$ & $<\mathrm{KH}$ & 116,00 & $<\mathrm{KH}$ & 180,00 \\
\hline S & $<\mathrm{KH}$ & $<\mathrm{KH}$ & 575,00 & $<\mathrm{KH}$ & 361,00 \\
\hline Sc & 0,85 & 1,25 & 1,53 & 0,73 & 4,39 \\
\hline $\mathrm{Sr}$ & 192,00 & 266,00 & 141,00 & 196,00 & 125,00 \\
\hline $\mathrm{Ti}$ & 23,60 & 132,00 & 56,40 & 9,88 & 1078,00 \\
\hline V & 2,83 & 8,51 & 13,80 & 1,34 & 48,10 \\
\hline $\mathrm{Y}$ & 1,01 & 2,34 & 2,52 & 0,72 & 9,16 \\
\hline $\mathrm{Yb}$ & 0,56 & 0,73 & 0,72 & 0,56 & 2,23 \\
\hline $\mathrm{Zn}$ & 7,89 & 15,10 & 597,00 & 4,64 & 906,00 \\
\hline
\end{tabular}

Megjegyzés: P1: 1. mintavételi hely a mészüzemben, P2: 2. mintavételi hely a mészüzemben, C: szálló por a cementgyárból, H: szálló por a hidrát üzemboól, T: tetô.

Table 1. Concentrations of elements taken from different stages of the filtration process $\left(\mathrm{mg} \mathrm{kg}^{-1}\right)$. (1) Elements ( $\left.\mathrm{mg} \mathrm{kg}^{-1}\right),(2)$ Origin of powder. Note: P1: sediment powder of quicklime factory, P2: air-borne powder of quicklime factory, C: air-borne powder of cement factory, $\mathrm{H}$ : air-borne powder of quicklime hydrate factory, T: powder from the roofs. 
2. táblázat. A gyártól eltérô távolságba vett levélminták elemanalizise

\begin{tabular}{cccccc}
\hline \multirow{2}{*}{$\begin{array}{c}\text { Elemek } \\
(\mathrm{mg} / \mathrm{kg})\end{array}$} & \multicolumn{5}{c}{$\begin{array}{c}\text { A gyártól mért távolság (m) } \\
(1)\end{array}$} \\
\cline { 2 - 6 }$(2)$ & $\begin{array}{c}\text { Kontroll } \\
(3)\end{array}$ & 200 & 400 & 600 & 800 \\
\hline $\mathrm{Al}$ & $96,50 \pm 16,9$ & $85,30 \pm 26,8$ & $78,06 \pm 27,0$ & $47,93 \pm 19,4$ & $53,44 \pm 30,2$ \\
$\mathrm{Cd}$ & $0,22 \pm<0,1$ & $0,14 \pm 0,1$ & $0,07 \pm 0,0$ & $0,04 \pm 0,0$ & $0,04 \pm, 0$ \\
$\mathrm{Cr}$ & $3,56 \pm 0,6$ & $0,64 \pm 0,4$ & $0,79 \pm 0,4^{*}$ & $0,46 \pm 0,1$ & $0,47 \pm 0,1$ \\
$\mathrm{~F}$ & $164,00 \pm 43,8$ & $143,33 \pm 32,9$ & $167,40 \pm 24,9$ & $142,33 \pm 23,2$ & $147,76 \pm 39,5$ \\
$\mathrm{Ni}$ & $3,75 \pm 0,7$ & $0,91 \pm 0,4^{*}$ & $1,35 \pm 0,7$ & $1,41 \pm 0,9$ & $1,05 \pm 0,4^{*}$ \\
\hline
\end{tabular}

Megjegyzés: $\left(\mathrm{n}=5 \pm\right.$ s.e.) (a kontrollhoz viszonyítva $\left.\mathrm{p}<0,05^{*}\right)$

Table 2. Element analysis of leaf samples which were taken at different distances from the factory. (1) Distance from the factory, (2) Elements $\left(\mathrm{mg} \mathrm{kg}^{-1}\right)$, (3) Control. Note: ( $\mathrm{n}=5 \pm$ s.e.) (compared to the control $\left.\mathrm{p}<0.05^{*}\right)$.

A magas kontroll értékekre az utólagos vizsgálatok adtak magyarázatot. A gyártól dél-nyugatra elterülő mintavételi terület erôsen agyagos talajú, pH-ja átlagosan 7,9, míg a kontroll minta területének talaja lazább, a pH-ja 6,5 volt. Az eltérô pH magyarázattal szolgálhat a kontrol területen élő növények magasabb Al, Cd, Cr, Fe és nikkel tartalmára. Ezeknek az elemeknek az oldékonysága a pH csökkenésével fokozódik, nô a mobilitásuk is a talajban (Lehoczky et al. 1997). Ezek a tényezôk a vizsgált elemek fokozott felvételét eredményezik.

A 2. táblázat adataiból kitúnik, hogy a nikkel kivételével valamennyi vizsgált elem koncentrációja csökken a levelekben, a gyártól való távolság függvényében. A nikkel esetében ilyen összefüggést nem tudunk kimutatni, ami megkérdőjelezi a nikkel ipari eredetét. Nem változott jelentôsen a vas mennyisége sem a távolság függvényében. A legközelebbi mintavételi helyen mért alacsony koncentráció valószínúleg a talajadottságokkal magyarázható. A területet korábban agyagos földdel töltötték fel a 3. számú főút Miskolcra bevezetô szakaszának bôvítésekor. A magas agyagtartalmú területeken a vas felvétele akadályozott. Annak eldöntésére, hogy a levelek eltéró elemtartalma az ipari porszennyezésen kívül milyen egyéb okokra vezethető, további vizsgálatok szükségesek. A terület bejárása során megállapítottuk, hogy a növényzet nem mutat toxikózisra utaló tüneteket. További eltérések okozója lehet a mintavételbe eső kertek eltérô kezelése. Az alkalmazott mútrágyák, különösen a nitrogén trágyák jelentôsen befolyásolják más tápelemek felvételét is, miközben 
a talajt, az alkalmazott koncentrációtól függóen eltérő mértékben savanyíthatják.

A szabadföldi területrôl vett minták eredményeinek ellentmondásossága miatt laboratóriumi kísérleteket állítottunk be. Kontrollált körülmények között vizsgáltuk a porminták fiziológiai hatásait. Mustármagvak felhasználásával toxikológiai tesztet végeztünk. A porokat a Petri-csészék alján terítettük, majd nedvesítettük és nedves szúrőpapírral fedtük, minden Petri-csészébe 100 szemet raktunk.

A mészüzem valamennyi pora erôsen alkalikus. Az oldékonyságuk csekély, viszont még kis mennyiségben oldódva is, jelentôs a fémoxid tartalom, a pH értéket rendkívüli módon megemeli. Az ellenôrző vizsgálatok során a mészgyárból származó valamennyi por oldatának pH-ja 12 pH feletti volt, a cementgyári por oldatáé 8 pH érték körüli. A csíráztatási kísérlet adatait a 3. táblázatban foglaltuk össze.

Feltételezésünk szerint ez lehetett az oka a rendkívül alacsony csírázási százaléknak. A cementgyár szálló porának hatása ellentétes. Az csírázási százalék végsô értékét tekintve nincs lényeges különbség a kontrolhoz viszonyítva, sôt a megismételt kísérletekben a cementpor kedvező hatását mutattuk ki. Magyarázat lehet a cementpor kedvezó hatására annak viszonylag magas nikkel tartalma, ugyanis Horak (1985) említi a nikkel csírázást serkentő hatását.

A vizsgálat során a csírázási százalékon kívül vizsgáltuk a csírázási erélyt is (3. táblázat), mint az egyik legfontosabb értékmérô tulajdonságot. A cementgyári por a kontrollhoz hasonló eredményt adott a csírázási százalékban, azonban a csírázási erély a cementipari pornál jelentősen, mintegy 21,5\%-kal magasabb volt a csíráztatás második napján mért eredmények szerint. A fokozott csírázási erély azt jelenti, hogy a magvak túlnyomó része hamar és egy időben csírázik, ami a kelést is egyidejûvé teszi, ennek eredményeként a növényállomány is kiegyenlített lesz, ami a későbbi nagy termés egyik előfeltétele.

Annak eldöntésére, hogy a tápoldatba adott porok pH- vagy ozmotikus stresszorként hatottak-e, vizsgáltuk a növények elemösszetételét. A 4-7. táblázat a napraforgóban mért elemkoncentrációkat mutatja. 
3. táblázat. A különbözö helyrôl származó filter porok hatása a mustár csírázási-képesességére

\section{Kezelések}

(1)

\begin{tabular}{cccccc} 
Mérési & Kontroll & P1 & P2 & C & H \\
\cline { 2 - 4 } & $(3)$ & & & & \\
\hline$(2)$ & & & & Kicsir
\end{tabular}

Kicsírázott magvak (\%)

(4)

\begin{tabular}{crcccc}
\hline 2 & $56,0 \pm 5,6$ & $2,0 \pm 1,4^{* * *}$ & $0,5 \pm 0,7^{* * *}$ & $77,5 \pm 10,6^{*}$ & $1,0 \pm 1,4^{* * *}$ \\
3 & $24,0 \pm 5,6$ & $0,0 \pm 0,0^{* * *}$ & $0,0 \pm 0,0^{* * *}$ & $8,5 \pm 2,1^{* * *}$ & $0,0 \pm 0,0^{* * *}$ \\
4 & $9,5 \pm 0,7$ & $1,5 \pm 0,7^{* *}$ & $0,5 \pm 0,7^{* * *}$ & $4,0 \pm 1,4^{* *}$ & $0,5 \pm 0,7^{* * *}$ \\
7 & $4,5 \pm 3,5$ & $0,0 \pm 0,0^{* * *}$ & $0,0 \pm 0,0^{* * *}$ & $3,0 \pm 1,4^{* * *}$ & $0,0 \pm 0,0^{* * *}$ \\
Összesen & & & & & 1,0 \\
$(5)$ & 94,0 & 3,5 & 1,0 & 93,0 & 1,0 \\
\hline
\end{tabular}

Megjegyzés: $\left(\mathrm{n}=2 \pm\right.$ s.e.) (kontrollhoz viszonyítva $\left.\mathrm{p}<0,05^{*}, \mathrm{p}<0,01^{* *}, \mathrm{p}<0,001^{* * *}\right)$. P1: 1 . mintavételi hely a mészüzemben, P2: 2. mintavételi hely a mészüzemben, C: szálló por a cementgyárból, H: szálló por a hidrát üzemből. *: A tört értékek az ismétlések számából erednek.

Table 3. Different filter powder effects on the germination ability of mustard seedlings. (1) Treatments, (2) Measurement days, (3) Control, (4) Germinated seeds (\%), (5) Total, Note: ( $\mathrm{n}=2 \pm$ s.e.) (compared to the control $\left.\mathrm{p}<0.05^{*}, \mathrm{p}<0.01^{* *}, \mathrm{p}<0.001^{* * *}\right)$. P1: sediment powder of quicklime factory, P2: air-borne powder of quicklime factory, C: air-borne powder of cement factory, $\mathrm{H}$ : air-borne powder of quicklime hydrate factory, ${ }^{*}$ : Fractions result from the number of replications.

A kísérleti eredmények az mutatják, hogy a növények a vizsgált elemeket az alkalmazott koncentrációktól függetlenül vették fel. Nincs arányos különbség az egyszeres $\left(1,25 \mathrm{~g} / 2,5 \mathrm{dm}^{-3}\right)$ és a tízszeres $\left(12,5 \mathrm{~g} / 2,5 \mathrm{dm}^{-3}\right)$ kezelések eredményei között. A cementgyári por esetében azonban jelentősen nôtt az alumínium koncentrációja a gyökérben, miközben a koncentrációja a hajtásban a kimutatási érték alatt maradt. A gyökerek magas Al koncentrációja a növény pusztulását okozhatja. Az Al által okozott erdôpusztulások okaként, a savas esốt a talaj lecsökkent pH-ja miatt megnövekedett talajoldat Al koncentrációt, ill. ezek következményeként a lombozatba került nagy mennyiségú alumíniumot említik (Murach és Ulrich 1988). A cementgyári por kedvezó hatása feltehetốen a tápoldat pH-jával van összefüggésben. Feltételezzük, hogy az alumínium ilyen körülmények között inaktiválódik a gyökérben és ezért nem tudja kedvezôtlen fiziológiai hatást kifejteni. Említést érdemel a vas, amely ugyan- 
csak a cementgyári porral kiegészített tápoldaton nevelt növényekben volt a legmagasabb koncentrációban.

4. táblázat. A vizsgált elemek koncentrációja napraforgó növények hajtásában ( $m g / k g)$

\begin{tabular}{crrrrr}
\hline \multirow{2}{*}{$\begin{array}{c}\text { Elemek } \\
(2)\end{array}$} & \multicolumn{5}{c}{$\begin{array}{c}\text { Kezelések } \\
(1)\end{array}$} \\
\cline { 2 - 6 } & Kontroll & P1 & P2 & C & H \\
\hline $\mathrm{Al}$ & $\mathrm{ND}$ & $\mathrm{ND}$ & $\mathrm{ND}$ & $\mathrm{ND}$ & $\mathrm{ND}$ \\
$\mathrm{Cd}$ & $\mathrm{ND}$ & 0,05 & 0,06 & 0,18 & 0,13 \\
$\mathrm{Cr}$ & 0,28 & 0,13 & 0,68 & 0,25 & 0,57 \\
$\mathrm{Fe}$ & 259,00 & 31,40 & 31,20 & 491,00 & 41,00 \\
$\mathrm{Ni}$ & 0,26 & 0,85 & 0,96 & 0,42 & 1,50 \\
\hline
\end{tabular}

Megjegyzés: A kísérleti edényekbe (2,5 dm³) 1,25 g került a vizsgált anyagból. P1: 1. mintavételi hely a mészüzemben, P2: 2 . mintavételi hely a mészüzemben, C: szálló por a cementgyárból, H: szálló por a hidrát üzemből, ND: nincs detektálható érték.

Table 4. Concentrations of examined elements in shoots of sunflowers ( $\left.\mathrm{mg} \mathrm{kg}^{-1}\right)$. (1) Treatments, (2) Elements, (3) Control. Note: 1.25 g examined matter were taken in the experimental pots $\left(2.5 \mathrm{dm}^{-3}\right) . \mathrm{P} 1$ : sediment powder of quicklime factory, P2: air-borne powder of quicklime factory, C: air-borne powder of cement factory, $\mathrm{H}$ : air-borne powder of quicklime hydrate factory, ND: no detectable value.

Feltételeztük, hogy az egyszikú kukorica eltérố módon reagál a kezelésekre. A mérési eredményeket a 8-11. táblázat mutatja be.

Annak ellenére, hogy a kétszikú napraforgó, és az egyszikú kukorica tápanyagfelvételi mechanizmusa eltérô, a felvett elemek tekintetében nem mutatkozik lényeges eltérés, a kéttényezős varianciaanalízis szerint sem mutat szignifikáns különbséget. Azonos körülmények között a kétszikúek nehézfém felvétele általában nagyobb, mint az egyszikúeké (Kádár 1991). Ez a tendencia labor kísérletünkben is tetten érhetô volt. A kétszikúek érzékenyebbek a rizoszféra pH-jára, már enyhén bázikus körülmények gátolják tápanyagfelvételüket azáltal, hogy a magas pH semlegesíti a gyökerek proton kiválasztását, ezért a $\mathrm{H}^{+}$-hoz kötött transzportfolyamatok, mint az antiport és a szimport erôsen gátlódnak (Sutclifee 1982). A transzportfolyamatok gátlása az alapvetô tápelemektől fosztja meg a növényt, így a növekedés megtorpan. 


\begin{tabular}{crrrrr}
\hline \multirow{5}{*}{$\begin{array}{c}\text { Elemek } \\
(2)\end{array}$} & \multicolumn{5}{c}{$\begin{array}{c}\text { Kezelések } \\
(1)\end{array}$} \\
\cline { 2 - 6 } & Kontroll & \multicolumn{1}{c}{ P1 } & \multicolumn{1}{c}{$\mathrm{P} 2$} & \multicolumn{1}{c}{$\mathrm{C}$} & \multicolumn{1}{c}{$\mathrm{H}$} \\
\hline $\mathrm{Al}$ & $\mathrm{ND}$ & $\mathrm{ND}$ & $\mathrm{ND}$ & 172,00 & 0,36 \\
$\mathrm{Cd}$ & $\mathrm{ND}$ & $\mathrm{ND}$ & 0,16 & 0,13 & 0,44 \\
$\mathrm{Cr}$ & 1,30 & 0,46 & 0,27 & 1,77 & 0,42 \\
$\mathrm{Fe}$ & 869,00 & 1122,00 & 234,00 & 1181,00 & 253,00 \\
$\mathrm{Ni}$ & 0,69 & 0,36 & 0,53 & 0,84 & 0,83 \\
\hline
\end{tabular}

Megjegyzés: A kísérleti edényekbe $\left(2,5 \mathrm{dm}^{-3}\right) 1,25 \mathrm{~g}$ került a vizsgált anyagból. P1: 1. mintavételi hely a mészüzemben, P2: 2. mintavételi hely a mészüzemben, C: szálló por a cementgyárból, H: szálló por a hidrát üzembôl, ND: nincs detektálható érték.

Table 5. Concentrations of examined elements in roots of sunflowers ( $\left.\mathrm{mg} \mathrm{kg}^{-1}\right)$. (1) Treatments, (2) Elements, (3) Control. Note: $1.25 \mathrm{~g}$ examined matter were taken in the experimental pots $\left(2.5 \mathrm{dm}^{-3}\right)$. P1: sediment powder of quicklime factory, P2: air-borne powder of quicklime factory, $\mathrm{C}$ : air-borne powder of cement factory, $\mathrm{H}$ : air-borne powder of quicklime hydrate factory, ND: no detectable value.

6. táblázat. A vizsgált elemek koncentrációja napraforgó növények hajtásában ( $\mathrm{mg} / \mathrm{kg}$ )

\begin{tabular}{crrrrr}
\hline \multirow{2}{*}{$\begin{array}{c}\text { Elemek } \\
(2)\end{array}$} & \multicolumn{5}{c}{$\begin{array}{c}\text { Kezelések } \\
(1)\end{array}$} \\
\cline { 2 - 6 } & Kontroll & P1 & P2 & C & H \\
\hline $\mathrm{Al}$ & $\mathrm{ND}$ & $\mathrm{ND}$ & $\mathrm{ND}$ & $\mathrm{ND}$ & $\mathrm{ND}$ \\
$\mathrm{Cd}$ & $\mathrm{ND}$ & 0,22 & 0,03 & 0,38 & 0,01 \\
$\mathrm{Cr}$ & 0,28 & 0,19 & 0,19 & 1,02 & 0,24 \\
$\mathrm{Fe}$ & 259,00 & 51,80 & 61,30 & 491,00 & 37,60 \\
$\mathrm{Ni}$ & 0,26 & 2,33 & 2,56 & 0,39 & 2,15 \\
\hline
\end{tabular}

Megjegyzés: A kísérleti edényekbe (2,5 dm³) 12,5 g került a vizsgált anyagból. P1: 1. mintavételi hely a mészüzemben, P2: 2. mintavételi hely a mészüzemben, C: szálló por a cementgyárból, H: szálló por a hidrát üzemből, ND: nincs detektálható érték.

Table 6. Concentrations of examined elements in shoots of sunflowers ( $\left.\mathrm{mg} \mathrm{kg}^{-1}\right)$. (1) Treatments, (2) Elements, (3) Control. Note: $12.5 \mathrm{~g}$ examined matter were taken in the experimental pots $\left(2.5 \mathrm{dm}^{-3}\right)$. P1: sediment powder of quicklime factory, P2: air-borne powder of quicklime factory, $\mathrm{C}$ : air-borne powder of cement factory, $\mathrm{H}$ : air-borne powder of quicklime hydrate factory, ND: no detectable value. 
7. táblázat. A vizsgált elemek koncentrációja napraforgó növények gyökerében ( $m g / k g$ )

\begin{tabular}{crrrrr}
\hline \multirow{2}{*}{$\begin{array}{c}\text { Elemek } \\
(2)\end{array}$} & \multicolumn{5}{c}{$\begin{array}{c}\text { Kezelések } \\
(1)\end{array}$} \\
\cline { 2 - 6 } & $\begin{array}{r}\text { Kontroll } \\
(3)\end{array}$ & P1 & \multicolumn{1}{c}{$\mathrm{P} 2$} & \multicolumn{1}{c}{$\mathrm{C}$} & $\mathrm{H}$ \\
\hline $\mathrm{Al}$ & $\mathrm{ND}$ & 16,60 & 9,47 & 435,00 & 6,65 \\
$\mathrm{Cd}$ & $\mathrm{ND}$ & 0,25 & 0,21 & 1,06 & 0,13 \\
$\mathrm{Cr}$ & 1,30 & 0,29 & 0,24 & 2,80 & 0,35 \\
$\mathrm{Fe}$ & 869,00 & 80,80 & 101,00 & 2290,00 & 113,00 \\
$\mathrm{Ni}$ & 0,69 & 0,86 & 0,68 & 1,16 & 0,71 \\
\hline
\end{tabular}

Megjegyzés: A kísérleti edényekbe $\left(2,5 \mathrm{dm}^{-3}\right) 12,5 \mathrm{~g}$ került a vizsgált anyagból. P1: 1 . mintavételi hely a mészüzemben, P2: 2 . mintavételi hely a mészüzemben, C: szálló por a cementgyárból, H: szálló por a hidrát üzemből, ND: nincs detektálható érték.

Table 7. Concentrations of examined elements in roots of sunflowers $\left(\mathrm{mg} \mathrm{kg}^{-1}\right)$. (1) Treatments, (2) Elements, (3) Control. Note: $12.5 \mathrm{~g}$ examined matter were taken in the experimental pots $\left(2.5 \mathrm{dm}^{-3}\right)$. P1: sediment powder of quicklime factory, P2: air-borne powder of quicklime factory, C: air-borne powder of cement factory, H: air-borne powder of quicklime hydrate factory, ND: no detectable value.

8. táblázat. A vizsgált elemek koncentrációja a kukorica hajtásában ( $m g / k g)$

\begin{tabular}{crrrrr}
\hline \multirow{2}{*}{$\begin{array}{c}\text { Elemek } \\
(2)\end{array}$} & $\begin{array}{c}\text { Kezelések } \\
(1)\end{array}$ \\
\cline { 2 - 6 } & Kontroll & P1 & P2 & C & H \\
\hline $\mathrm{Al}$ & $\mathrm{ND}$ & $\mathrm{ND}$ & $\mathrm{ND}$ & $\mathrm{ND}$ & $\mathrm{ND}$ \\
$\mathrm{Cd}$ & $\mathrm{ND}$ & $\mathrm{ND}$ & $\mathrm{ND}$ & 0,03 & $\mathrm{ND}$ \\
$\mathrm{Cr}$ & 0,35 & 0,14 & 0,23 & 0,36 & 0,16 \\
$\mathrm{Fe}$ & 97,50 & 65,50 & 49,40 & 70,40 & 52,50 \\
$\mathrm{Ni}$ & 0,50 & 0,25 & 0,50 & 0,44 & 0,21 \\
\hline
\end{tabular}

Megjegyzés: A kísérleti edényekbe (2,5 dm³) 1,25 g került a vizsgált anyagból. P1: 1. mintavételi hely a mészüzemben, P2: 2 . mintavételi hely a mészüzemben, C: szálló por a cementgyárból, H: szálló por a hidrát üzemből, ND: nincs detektálható érték.

Table 8. Concentrations of examined elements in shoots of corns $\left(\mathrm{mg} \mathrm{kg}^{-1}\right)$. (1) Treatments, (2) Elements, (3) Control. Note: $1.25 \mathrm{~g}$ examined matter were taken in the experimental pots $\left(2.5 \mathrm{dm}^{-3}\right)$. P1: sediment powder of quicklime factory, P2: air-borne powder of quicklime factory, C: air-borne powder of cement factory, $\mathrm{H}$ : air-borne powder of quicklime hydrate factory, ND: no detectable value. 
9. táblázat. A vizsgált elemek koncentrációja a kukorica gyökerében (mg/kg)

\begin{tabular}{|c|c|c|c|c|c|}
\hline \multirow{2}{*}{$\begin{array}{c}\text { Elemek } \\
\text { (2) }\end{array}$} & \multicolumn{5}{|c|}{$\begin{array}{c}\text { Kezelések } \\
\text { (1) }\end{array}$} \\
\hline & $\begin{array}{c}\text { Kontroll } \\
\text { (3) }\end{array}$ & P1 & $\mathrm{P} 2$ & $\mathrm{C}$ & $\mathrm{H}$ \\
\hline $\mathrm{Al}$ & 13,90 & ND & 74,10 & 410,00 & 15,60 \\
\hline $\mathrm{Cd}$ & ND & ND & 0,24 & 1,20 & 9,01 \\
\hline $\mathrm{Cr}$ & 2,11 & 0,71 & 1,03 & 1,92 & 4,04 \\
\hline $\mathrm{Fe}$ & 398,00 & 1674,00 & 270,00 & 1927,00 & 293,00 \\
\hline $\mathrm{Ni}$ & 2,80 & 1,12 & 1,70 & 3,52 & 16,10 \\
\hline
\end{tabular}

Megjegyzés: A kísérleti edényekbe (2,5 dm³) 1,25 g került a vizsgált anyagból. P1: 1. mintavételi hely a mészüzemben, P2: 2 . mintavételi hely a mészüzemben, C: szálló por a cementgyárból, $\mathrm{H}$ : szálló por a hidrát üzembôl, ND: nincs detektálható érték.

Table 9. Concentrations of examined elements in roots of corns ( $\left.\mathrm{mg} \mathrm{kg}^{-1}\right)$. (1) Treatments, (2) Elements, (3) Control. Note: $1.25 \mathrm{~g}$ examined matter were taken in the experimental pots $\left(2.5 \mathrm{dm}^{-3}\right)$. P1: sediment powder of quicklime factory, P2: air-borne powder of quicklime factory, C: air-borne powder of cement factory, $\mathrm{H}$ : air-borne powder of quicklime hydrate factory, ND: no detectable value.

10. táblázat. A vizsgált elemek koncentrációja a kukorica hajtásában ( $\mathrm{mg} / \mathrm{kg}$ )

\begin{tabular}{crrrrr}
\hline \multirow{2}{*}{$\begin{array}{c}\text { Elemek } \\
(2)\end{array}$} & \multicolumn{5}{c}{$\begin{array}{c}\text { Kezelések } \\
(1)\end{array}$} \\
\cline { 2 - 6 } & Kontroll & P1 & P2 & C & H \\
\hline $\mathrm{Al}$ & $\mathrm{ND}$ & $\mathrm{ND}$ & $\mathrm{ND}$ & $\mathrm{ND}$ & $\mathrm{ND}$ \\
$\mathrm{Cd}$ & $\mathrm{ND}$ & $\mathrm{ND}$ & $\mathrm{ND}$ & 0,10 & $\mathrm{ND}$ \\
$\mathrm{Cr}$ & 0,35 & 0,48 & 0,32 & 0,25 & 0,26 \\
$\mathrm{Fe}$ & 97,50 & 107,00 & 57,60 & 50,30 & 54,30 \\
$\mathrm{Ni}$ & 0,50 & 1,21 & 0,74 & 0,16 & 0,74 \\
\hline
\end{tabular}

Megjegyzés: A kísérleti edényekbe (2,5 dm³) 12,5 g került a vizsgált anyagból. P1: 1 . mintavételi hely a mészüzemben, P2: 2 . mintavételi hely a mészüzemben, C: szálló por a cementgyárból, $\mathrm{H}$ : szálló por a hidrát üzemből, ND: nincs detektálható érték.

Table 10. Concentrations of examined elements in roots of corns $\left(\mathrm{mg} \mathrm{kg}^{-1}\right)$. (1) Treatments, (2) Elements, (3) Control. Note: $12.5 \mathrm{~g}$ examined matter were taken in the experimental pots $\left(2.5 \mathrm{dm}^{-3}\right)$. P1: sediment powder of quicklime factory, P2: air-borne powder of quicklime factory, C: air-borne powder of cement factory, $\mathrm{H}$ : air-borne powder of quicklime hydrate factory, ND: no detectable value. 
11. táblázat. A vizsgált elemek koncentrációja a kukorica gyökerében ( $m g / k g)$

\begin{tabular}{crrrrr}
\hline \multirow{2}{*}{$\begin{array}{c}\text { Elemek } \\
(2)\end{array}$} & $\begin{array}{c}\text { Kezelések } \\
(1)\end{array}$ \\
\cline { 2 - 6 } & \multicolumn{1}{c}{ Kontroll } & \multicolumn{1}{c}{ P1 } & \multicolumn{1}{c}{ P2 } & \multicolumn{1}{c}{$\mathrm{C}$} & \multicolumn{1}{c}{$\mathrm{H}$} \\
\hline $\mathrm{Al}$ & 13,90 & $\mathrm{ND}$ & 45,90 & 544,00 & $\mathrm{ND}$ \\
$\mathrm{Cd}$ & $\mathrm{ND}$ & $\mathrm{ND}$ & 0,82 & 2,21 & 0,75 \\
$\mathrm{Cr}$ & 2,11 & 1,15 & 0,48 & 2,24 & 1,49 \\
$\mathrm{Fe}$ & 398,00 & 274,00 & 158,00 & 2191,00 & 138,00 \\
$\mathrm{Ni}$ & 2,80 & 2,21 & 1,07 & 2,80 & 4,59 \\
\hline
\end{tabular}

Megjegyzés: A kísérleti edényekbe (2,5 dm³) 12,5 g került a vizsgált anyagból. P1: 1. mintavételi hely a mészüzemben, P2: 2 . mintavételi hely a mészüzemben, C: szálló por a cementgyárból, H: szálló por a hidrát üzemből, ND: nincs detektálható érték.

Table 11. Concentrations of examined elements in roots of corns $\left(\mathrm{mg} \mathrm{kg}^{-1}\right)$. (1) Treatments, (2) Elements, (3) Control. Note: $12.5 \mathrm{~g}$ examined matter were taken in the experimental pots $\left(2.5 \mathrm{dm}^{-3}\right)$. P1: sediment powder of quicklime factory, P2: air-borne powder of quicklime factory, C: air-borne powder of cement factory, H: air-borne powder of quicklime hydrate factory, ND: no detectable value.

A számszerúsítéshez mértük a növények szárazanyag felhalmozását. A mérések eredményét a 12. táblázatban foglaltuk össze. A cementgyári poron kívül minden kezelés gátolta a hajtás és a gyökér növekedését mindkét növénynél. A hajtásnövekedés mérsékelt csökkenése figyelhetô meg a cementgyári por alkalmazásakor, azonban a gyökérnövekedést jelentósen serkentette. A kukoricánál 1,6-szor nagyobb volt a gyökértömeg, mint a kontrollnál. A hatás magyarázata további vizsgálatokat igényel, hiszen lényeges különbséget nem tapasztaltunk a porok paramétereinek összehasonlításakor. Az intenzívebb gyökérnövekedés kedvező, mert a növény nagyobb felületen tud vizet és tápanyagot felvenni, ezáltal nô a stressz toleranciája is (Kovda és Szabolcs 1979). A mérési eredmények felvetik a cementgyári por felhasználásának lehetôségét, akár mikroelem trágyaként, vagy gyökérnövekedést serkentô adalékanyagként.

A növények szerves anyag felhalmozása bonyolult biokémiai folyamatok összessége. Alapvetően a fotoszintézis és a légzés különbsége adja azt a szerves anyag tömeget, ami pl. egy vegetációs periódus végén a termést jelenti. A környezeti tényezők mindkét folyamat intenzitását meghatározzák, miközben a növény ultrastruktúrája, annak aktivitása a környezeti hatások érvényesülésé- 
nek a feltételei (Vigh et al. 1983). Hatékony szerves anyag felhalmozás nem lehetséges a fotoszintetikus folyamatok nélkülözhetetlen alkotója, a klorofill nélkül. Az alkalmazott kezelések hatására csökkent a szárazanyag-felhalmozás, ami mögött a csökkent fotoszintetikus aktivitást, illetve a klorofill tartalom változását feltételeztük. Méréseink szerint a kezelések befolyásolták a klorofill tartalmat (13. táblázat).

12. táblázat. Kukorica és napraforgó hajtásának és gyökerének száraz tömege

(g/növény)

\begin{tabular}{lcccc}
\hline & \multicolumn{2}{c}{ Kukorica } & \multicolumn{2}{c}{$\begin{array}{c}\text { Napraforgó } \\
\text { Kezelések }\end{array}$ (3) } \\
\cline { 2 - 5 } & Hajtás & Gyökér & Hajtás & Gyökér \\
& $(4)$ & $(5)$ & $(4)$ & $(5)$ \\
\hline Kontroll (6) & 0,11 & 0,17 & 0,12 & 0,34 \\
$1,25 \mathrm{H}$ & 0,03 & 0,10 & 0,04 & 0,11 \\
$12,5 \mathrm{H}$ & 0,01 & 0,09 & 0,04 & 0,06 \\
$1,25 \mathrm{C}$ & 0,09 & 0,28 & 0,07 & 0,37 \\
$12,5 \mathrm{C}$ & 0,08 & 0,26 & 0,07 & 0,41 \\
$1,25 \mathrm{P} 1$ & 0,07 & 0,24 & 0,05 & 0,10 \\
$12,5 \mathrm{P} 1$ & 0,01 & 0,07 & 0,02 & 0,07 \\
$1,25 \mathrm{P} 2$ & 0,04 & 0,11 & 0,05 & 0,11 \\
$12,5 \mathrm{P} 2$ & 0,05 & 0,09 & 0,04 & 0,07 \\
\hline
\end{tabular}

Megjegyzés: P1: 1. mintavételi hely a mészüzemben, P2: 2. mintavételi hely a mészüzemben, C: szálló por a cementgyárból, H: szálló por a hidrát üzembốl.

Table 12. Dry matter of corn and sunflower of roots and shoots (g plant $t^{-1}$ ). (1) Maize, (2) Sunflower, (3) Treatments, (4) Shoot, (5) Root, (6) Control. Note: P1: sediment powder of quicklime factory, P2: air-borne powder of quicklime factory, C: air-borne powder of cement factory, H: air-borne powder of quicklime hydrate factory.

A kezelések bár hatottak a klorofill tartalomra, de ez a hatás korántsem olyan kifejezett, mint a száraztömeg alakulására gyakorolt hatás. A cementgyári por ebben az esetben is a kontroll feletti klorofill tartalmat eredményezett. A mérési adatok alapján azt a következtetést vonhatjuk le, hogy a klorofill szintézis kevésbé érzékeny a kezelések okozta kedvezôtlen hatásokra.

A viszonylag magas értékeket az magyarázhatja, hogy a meglehetôsen stabil klorofill szintézis a csökkent tömegú hajtásban magasabb relatív értéket 
mutat. A táblázat adatai alapján az is valószínúsíthető, hogy a klorofill tartalomban bekövetkezô mérsékelt csökkenés is a szárazanyag felhalmozás számottevố csökkenését eredményezi. Ezt az állítást megerôsíti a 12. valamint a 13. táblázat összehasonlítása.

13. táblázat. Kukorica és napraforgó növények relatív klorofill tartalmának alakulása (Spad unit)

\begin{tabular}{lccc}
\hline & \multicolumn{2}{c}{ Kukorica } & Napraforgó \\
Kezelések & \multicolumn{2}{c}{$(1)$} & $(2)$ \\
\cline { 2 - 4 }$(3)$ & 2. levél & 3. levél & 1. lomblevél \\
& $(4)$ & $(5)$ & $(6)$ \\
\hline Kontroll (7) & $44,53 \pm 2,9$ & $39,38 \pm 3,2$ & $43,62 \pm 1,1$ \\
$1,25 \mathrm{H}$ & $39,90 \pm 1,4$ & $27,70 \pm 7,7^{*}$ & $32,63 \pm 1,2^{*}$ \\
$12,5 \mathrm{H}$ & $35,06 \pm 3,9^{*}$ & $29,43 \pm 3,6^{*}$ & $28,55 \pm 1,9^{*}$ \\
$1,25 \mathrm{C}$ & $40,90 \pm 1,8$ & $35,80 \pm 1,8$ & $43,43 \pm 2,3$ \\
$12,5 \mathrm{C}$ & $45,70 \pm 4,6$ & $36,30 \pm 3,1$ & $44,75 \pm 1,1$ \\
$1,25 \mathrm{P} 1$ & $35,43 \pm 1,5^{*}$ & $29,58 \pm 1,3$ & $29,30 \pm 3,6^{*}$ \\
$12,5 \mathrm{P} 1$ & $28,05 \pm 7,6^{* *}$ & $27,65 \pm 7,7^{*}$ & $27,67 \pm 3,6^{*}$ \\
$1,25 \mathrm{P} 2$ & $35,33 \pm 0,6^{*}$ & $27,10 \pm 3,0^{* *}$ & $31,45 \pm 2,0^{*}$ \\
$12,5 \mathrm{P} 2$ & $36,50 \pm 0,6$ & $32,00 \pm 4,1$ & $34,87 \pm 2,9^{*}$ \\
\hline
\end{tabular}

Megjegyzés: $\mathrm{n}=35 \pm$ s.e. (kontrollhoz viszonyítva $\mathrm{p}<0,05^{*}, \mathrm{p}<0,01^{* *}$ ). P1: 1 . mintavételi hely a mészüzemben, P2: 2. mintavételi hely a mészüzemben, C: szálló por a cementgyárból, H: szálló por a hidrát üzemból.

Table 13. Relative chlorophyll contents of corn and sunflower leaves (Spad units). (1) Maize, (2) Sunflower, (3) Treatments, (4) $2^{\text {nd }}$ leaf (5) $3^{\text {rd }}$ leaf (6) $1^{\text {st }}$ foliage-leaf, (7) Control. Note: $\mathrm{n}=35 \pm$ s.e. (compared to the control: $\mathrm{p}<0.05^{*}, \mathrm{p}<0.01^{* *}$ ). P1: sediment powder of quicklime factory, P2: air-borne powder of quicklime factory, C: air-borne powder of cement factory, $\mathrm{H}$ : air-borne powder of quicklime hydrate factory.

A különbözô helyekrôl vett porminták növényfiziológiai vizsgálati alapján azt a következtetést vonhatjuk le, hogy a közel azonos kémiai összetételú porok hatásai között lényeges különbségek vannak. A porokkal kiegészített tápoldaton nevelt növények tápelem összetételében ugyanakkor nem mutatkozott számottevő különbség. Ebből arra a következtetésre jutottunk, hogy a növény a tápoldatból nem vette fel, illetve nem akkumulálta a porban található elemeket, ezért a növekedés gátlása más okra, így például pH-, vagy ozmotikus stresszre vezethetô vissza. 


\section{IRODALOM}

Birkás M.: 2009. A klasszikus talajmúvelési elvárások és a klímakár csökkentés kényszere. Növénytermelés. 58. 2: 123-134.

Bollard, E. G.: 1983. Involvement of unusual elements in plant growth and nutrition. [In: Läuchli, A.-Bielski, R. L. (eds.) Encyclopedia of Plant Physiology, New Series.] Springer Verlag, Berlin and New York. 15B. 695-755.

Duxbury, T.: 1985. Ecological aspects of heavy metal responses in microorganisms. Adv. Microb. Ecol. 8: 185-235

Filep, Gy.-Dániel, P.-Kovács, B.-Loch, J.: 1998. Effect of various extractants and extractant/soil ratio on detected $\mathrm{Cu}, \mathrm{Pb}$ and $\mathrm{Cd}$ concentration. Soil Pollution. 113-123.

Foy, C. D.: 1983. The physiology of plant adaptation to mineral stress. [In: Carson, E. W. (ed.) The Plant Root and its Environment.] University Press. Virginia. Charlottesville. 601-642.

Horak, O.: 1985. Zur Bedeutung des Nickels für Fabaceae. II. Nickelaufnahme und Nickelbedarf von Pisum sativum L. Phyton. Austria. 25: 301-307.

Kádár, I.-Morvai, B.-Szabó, L.: 1998. Phytotoxicity of heavy metals in long-term field experiments. Soil Pollution.138-143

Kádár I.: 1991. A talajok és növények nehézfémtartalmának vizsgálata. Környezetvédelmi és Területfejlesztési Minisztérium. MTA Talajtani és Agrokémiai Kutató Intézete. Budapest.

Konishi, S.-Miyamoto, S.-Taki, T.: 1985. Stymulatory effects of aluminium on tea plants grown under low and high phosphorus supply. Soil. Sci. Plant Nutr. Tokyo. 31: 361-368.

Kovda, V. A.-Szabolcs, I.: 1979. Modelling of soil sanilization and alkalization. Agrokémia és Talajtan. 207.

Lehoczky É.-Szomolányi A.-Marth P.-Szabados I.: 1997. A talaj Cd-tartalmának hatása a fokhagymára. 3. Veszprémi Környezetvédelmi Konferencia és Kiállítás, 1997. május 26-28. Tanulmánykötet. 397-402.

Matsumoto, H.-Hirasawa, E.-Morimura, S.-Takahashi, E.: 1976. Localization of aluminium in tea leaves. Plant Cell Physiol. 17: 627-631.

Miller, G. W.-Huang, I. J.-Welkie, G. W.-Pushnik, J. C.: 1995. Function of iron in plants with spetial emphasis on chloroplasts and photosynthetic activity. [In: Abadia, J. (ed.) Iron Nutrition in Soil and Plants.] Kluwer Academic Press. Dordrecht. 19-28.

Murach, D.-Ulrich, B.: 1988. Destabilization of forest ecosystems by acid deposition. Geo J. 17. 2: 253-260.

Nagy J.: 2006. Az évjárat hatásának értékelése a kukorica termésére. Növénytermelés. 55. 5-6: 299-307.

Pinto, A. P.-Mota, A. M.-de Varennes, A.-Pinto, F. C.: 2004. Influence of organic matter on the uptake of cadmium, zinc, copper and iron by sorghum plants. Sci. Tot. Environ. 326: 239-247 
Simon L.-Vágvölgyi S.-Györi Z.: 1999. Kadmium akkumuláció vizsgálata napraforgó (Helianthus annus L.) növényben. Agrokémia és Talajtan. 48. 1-2: 99-108.

Sutclifee, J. F.: 1982. A növények és a víz. Mezógazdasági Kiadó. Budapest. 30-60.

Vér Zs.: 2006. Talajok különbözô oldhatóságú nehézfémtartalmának vizsgálata a Keszthelyi Országos Mútrágyázási Tartamkísérletekben. Doktori (PhD) értekezés. Pannon Egyetem Georgikon Mezőgazdaságtudományi Kar. Keszthely.

Vigh L.-Horváth I.-Farkas T.: 1983. A növények fagytûrố képességének és membránlipidjeinek fázisállapotának kapcsolata. A biológia aktuális problémái. Medicina Könyvkiadó. Budapest. 26: 120-201.

A szerzők levelezési címe - Address of the authors:

Tóth Brigitta-Dr. Veres Szilvia-Bákonyi Nóra-Gajdos Éva-Marozsán MariannaDr. Lévai László

Debreceni Egyetem

Agrár- és Gazdálkodástudományok Centruma

Növénytudományi Intézet

Mezőgazdasági Növénytani és Növényélettani Tanszékcsoport

Debrecen

Böszörményi út 138.

H-4032 